\title{
Immune-Checkpoint Inhibitors For The Treatment Of Non-Small Cell Lung Cancer: A Comparison Of The Regulatory Approvals In Europe And The United States
}

\author{
Remziye Zaim ( $\square$ zaim@eshpm.eur.nl) \\ Erasmus University Rotterdam

\section{Ken Redekop} \\ Erasmus University Rotterdam

\section{Carin A. Uyl-de Groot} \\ Erasmus University Rotterdam
}

\section{Short Report}

Keywords: Immune-Checkpoint Inhibitors, US Food and Drug Administration, European Medicines Agency, Regulatory Approvals

Posted Date: February 23rd, 2022

DOI: https://doi.org/10.21203/rs.3.rs-1379018/v1

License: (우 (i) This work is licensed under a Creative Commons Attribution 4.0 International License. Read Full License

Version of Record: A version of this preprint was published at Journal of Cancer Policy on September 1st, 2022. See the published version at https://doi.org/10.1016/j.jcpo.2022.100346. 


\section{Abstract}

The process of regulatory authorization of oncology drugs, including immune-checkpoint inhibitors, has been improved by the cooperation and coordination among the United States Food and Drug Administration (FDA) and the European Medicines Agency (EMA). Regulatory decisions of immune-checkpoint inhibitors by these agencies are often based on enhanced efficacy and acceptable toxicity profiles, investigated in randomized, open-label, clinical trials. In this study, we addressed the differences in regulatory approvals between the FDA and the EMA for immune-checkpoint inhibitors in the treatment of non-small cell lung cancer, from year 2015 until 2021; by focusing on: (1) time to approval of immune-checkpoint inhibitors, and (2) the considerations of patient-reported outcomes (PROs) by each agency. Both the FDA and the EMA recognize the value of PROs as important patient-centered endpoints when determining the efficacy of therapies, and considering drugs for approval. Despite similarities in the regulatory pathways and assessments used for immune-checkpoint inhibitor approvals, there are differences between the two agencies when time to approval or marketing authorization for these drugs were compared. Efforts to align regulatory practices, with high concordance approval outcomes, can lead to better use of resources associated with drug development. These efforts can also provide a more streamlined and predictable process for evaluation of the efficacy, safety and PRO measures for new immune-checkpoint inhibitors or disease indications. Further harmonization and collaboration between the EMA and the FDA on the PRO instrument development, measurement and validation are encouraged to increase the efficiency of the decision-making processes in the future.

\section{Introduction}

Advancements in drug development have increased the need for harmonization and collaboration among regulatory authorities. Regulatory approval decisions of the United States (US) Food and Drug Administration (FDA) and the European Medicines Agency (EMA) are often compared and contrasted, particularly on their drug or medicinal product review requirements, and time to approval or refusal decisions. These two regulatory agencies have adopted the guidelines of the International Council for Harmonization of Technical Requirements for Pharmaceuticals for Human Use, to facilitate harmonization and ensure safe, effective, and high-quality drug products. [1] Under the auspices of their confidentiality agreements, both the FDA and the EMA have established various mediums for information sharing, and collaboration around drug development and regulation. [2] These mediums (referred as 'clusters') bring together technical experts that share information on topics such as plans for manufacturing or clinical site inspections, oncology products, pharmacogenomics, biostatistics, rare diseases, vaccines and others. [2] Although the discussions on basics in regulatory science are a bedrock to facilitate alignment on high impact standards and methods, the decisions about marketing authorization for drugs must be made by the FDA and the EMA within their respective legal and regulatory frameworks.

The process of regulatory authorization of oncology drugs, including immune-checkpoint inhibitors, have been facilitated by the cooperation and coordination between the FDA and the EMA. Immune checkpoint blockade is an effective therapeutic strategy that harnesses the immune system to generate an antitumor response. [3] The regulatory decisions of immune-checkpoint inhibitors by these agencies are often based on enhanced efficacy and acceptable toxicity profiles, investigated in randomized, open-label, clinical trials. Although the ongoing cooperation has resulted in harmonized practices and requirements that have helped decrease regulatory 
burden and delays on decision-making processes, there remain important differences between these two agencies.

A better understanding of the regulatory environments in the US and Europe, as well as efforts to align the approaches of the respective drug approval agencies, can guide resource allocation, facilitate advances in cancer care, and ultimately optimize patient care. For example, high costs of non-small cell lung cancer (NSCLC) treatment are associated, in part, with the significant expenses of bringing new drugs to the market. In order to reduce the costs of development and facilitate innovative drug approvals, efforts have been made to align and streamline the regulatory environment within which drug efficacy and safety are evaluated. This is crucial for the approval of immune-checkpoint inhibitors, particularly in NSCLC, where there have been significant progress in understanding tumor biology, immunology and molecular targets. Therefore, in this study, we aim to address the differences in regulatory approvals between the FDA and the EMA for immune-checkpoint inhibitors in the treatment of NSCLC from year 2015 until 2021; by focusing on: (1) time to approval of immune-checkpoint inhibitors, and (2) the considerations of patient-reported outcomes (PROs) by each agency.

\section{Regulatory approvals of immune-checkpoint inhibitors in NSCLC}

From year 2015 until 2021, the FDA had approved 17 immune-checkpoint inhibitor indications, whereas, the EMA approved 12 of these indications for the treatment of NSCLC. (see Table 1) For the FDA approved indications, 11 were indicated for first-line treatment of patients with no prior treatment history. The remaining six indications were approved for previously treated NSCLC patients, namely: for second-line and third-line of treatments. For the EMA approved indications, seven were indicated for first-line patients with no prior treatment history, and the remaining five were approved for previously treated patients. Table 1 lists the clinical trials of the immune-checkpoint inhibitors, their respective approval dates by each agency, type of each approval (regular or accelerated), lines of each treatment, and PRO considerations.

Table 1: Regulatory approvals of immune-checkpoint inhibitors for the treatment of non-small cell lung cancer [2015-2021] 


\begin{tabular}{|c|c|c|c|c|c|c|}
\hline $\begin{array}{l}\text { Immune-Checkpoint } \\
\text { Inhibitor }\end{array}$ & $\begin{array}{l}\text { Clinical Trial(s) } \\
\text { [Number] }\end{array}$ & $\begin{array}{l}\text { US FDA } \\
\text { Approval }\end{array}$ & Type & $\begin{array}{l}\text { EMA } \\
\text { Approval }\end{array}$ & $\begin{array}{l}\text { Treatment } \\
\text { Line }\end{array}$ & PROs \\
\hline Nivolumab & $\begin{array}{l}\text { CheckMate 017 } \\
\text { [NCT01642004] } \\
\text { CheckMate 063 } \\
\text { [NCT01721759] }\end{array}$ & $\begin{array}{l}\text { March 4, } \\
2015\end{array}$ & $\begin{array}{l}\text { Regular } \\
\text { Approval }\end{array}$ & $\begin{array}{l}\text { September } \\
24,2015\end{array}$ & $\begin{array}{l}\text { Second- } \\
\text { line }\end{array}$ & $\checkmark$ \\
\hline Nivolumab & $\begin{array}{l}\text { CheckMate 057 } \\
\text { [NCT01673867] }\end{array}$ & $\begin{array}{l}\text { October } 9 \\
2015\end{array}$ & $\begin{array}{l}\text { Regular } \\
\text { Approval }\end{array}$ & $\begin{array}{l}\text { February } 25, \\
2016\end{array}$ & $\begin{array}{l}\text { Second- } \\
\text { line }\end{array}$ & $\checkmark$ \\
\hline Pembrolizumab & $\begin{array}{l}\text { KEYNOTE } 001 \\
\text { [NCT01295827] } \\
\text { KEYNOTE 010 } \\
\text { [NCT01905657] }\end{array}$ & $\begin{array}{l}\text { October 2, } \\
2015\end{array}$ & $\begin{array}{l}\text { Accelerated } \\
\text { Approval }\end{array}$ & $\begin{array}{l}\text { June 23, } \\
2016\end{array}$ & $\begin{array}{l}\text { Second- } \\
\text { line }\end{array}$ & $\checkmark$ \\
\hline Pembrolizumab & $\begin{array}{l}\text { KEYNOTE 024 } \\
\text { [NCT02142738] }\end{array}$ & $\begin{array}{l}\text { October } \\
24,2016\end{array}$ & $\begin{array}{l}\text { Regular } \\
\text { Approval }\end{array}$ & $\begin{array}{l}\text { December } \\
15,2016\end{array}$ & First-line & $\checkmark$ \\
\hline Atezolizumab & $\begin{array}{l}\text { Poplar } \\
\text { [NCT01903993] } \\
\text { OAK } \\
\text { [NCT02008227] }\end{array}$ & $\begin{array}{l}\text { October } \\
18,2016\end{array}$ & $\begin{array}{l}\text { Regular } \\
\text { Approval }\end{array}$ & $\begin{array}{l}\text { July 20, } \\
2017\end{array}$ & $\begin{array}{l}\text { Second- } \\
\text { line }\end{array}$ & $\checkmark$ \\
\hline $\begin{array}{l}\text { Pembrolizumab } \\
\text { combination } \\
\text { (Pemetrexed + } \\
\text { Carboplatin) }\end{array}$ & $\begin{array}{l}\text { KEYNOTE 021 } \\
\text { [NCT02039674] }\end{array}$ & $\begin{array}{l}\text { May 10, } \\
2017\end{array}$ & $\begin{array}{l}\text { Accelerated } \\
\text { Approval }\end{array}$ & $\begin{array}{l}\text { Application } \\
\text { Withdrawn }\end{array}$ & First-line & - \\
\hline Durvalumab & $\begin{array}{l}\text { PACIFIC } \\
\text { [NCT02125461] }\end{array}$ & $\begin{array}{l}\text { February } \\
16,2018\end{array}$ & $\begin{array}{l}\text { Regular } \\
\text { Approval }\end{array}$ & $\begin{array}{l}\text { July } 26 \\
2018\end{array}$ & Third-line & $\checkmark$ \\
\hline $\begin{array}{l}\text { Pembrolizumab } \\
\text { combination } \\
\text { (Pemetrexed + } \\
\text { Carboplatin/Cisplatin) }\end{array}$ & $\begin{array}{l}\text { KEYNOTE 189 } \\
\text { [NCT02578680] }\end{array}$ & $\begin{array}{l}\text { August } \\
20,2018\end{array}$ & $\begin{array}{l}\text { Regular } \\
\text { Approval }\end{array}$ & $\begin{array}{l}\text { July } 26 \\
2018\end{array}$ & First-line & $\checkmark$ \\
\hline $\begin{array}{l}\text { Pembrolizumab } \\
\text { combination } \\
\text { (Paclitaxel or Nab- } \\
\text { Paclitaxel) }\end{array}$ & $\begin{array}{l}\text { KEYNOTE 407 } \\
\text { [NCT02775435] }\end{array}$ & $\begin{array}{l}\text { October } \\
30,2018\end{array}$ & $\begin{array}{l}\text { Regular } \\
\text { Approval }\end{array}$ & $\begin{array}{l}\text { January 31, } \\
2019\end{array}$ & First-line & $\checkmark$ \\
\hline $\begin{array}{l}\text { Atezolizumab } \\
\text { combination } \\
\text { (Bevacizumab, } \\
\text { Carboplatin, } \\
\text { Paclitaxel) }\end{array}$ & $\begin{array}{l}\text { IMpower } 150 \\
\text { [NCT02366143] }\end{array}$ & $\begin{array}{l}\text { December } \\
6,2018\end{array}$ & $\begin{array}{l}\text { Regular } \\
\text { Approval }\end{array}$ & $\begin{array}{l}\text { January 31, } \\
2019\end{array}$ & First-line & $\checkmark$ \\
\hline Pembrolizumab & $\begin{array}{l}\text { KEYNOTE 042 } \\
\text { [NCT02220894] }\end{array}$ & $\begin{array}{l}\text { April 11, } \\
2019\end{array}$ & $\begin{array}{l}\text { Regular } \\
\text { Approval }\end{array}$ & $\begin{array}{l}\text { Not } \\
\text { Approved }\end{array}$ & First-line & - \\
\hline $\begin{array}{l}\text { Atezolizumab } \\
\text { combination } \\
\text { (Carboplatin/Nab- } \\
\text { Paclitaxel) }\end{array}$ & $\begin{array}{l}\text { IMpower } 130 \\
\text { [NCT02367781] }\end{array}$ & $\begin{array}{l}\text { December } \\
3,2019\end{array}$ & $\begin{array}{l}\text { Regular } \\
\text { Approval }\end{array}$ & $\begin{array}{l}\text { July } 25 \\
2019\end{array}$ & First-line & $\checkmark$ \\
\hline $\begin{array}{l}\text { Nivolumab + } \\
\text { Ipilimumab } \\
\text { combination }\end{array}$ & $\begin{array}{l}\text { CheckMate 227 } \\
\text { [NCT02477826] }\end{array}$ & $\begin{array}{l}\text { May 15, } \\
2020\end{array}$ & $\begin{array}{l}\text { Regular } \\
\text { Approval }\end{array}$ & $\begin{array}{l}\text { Application } \\
\text { Withdrawn }\end{array}$ & First-line & $\checkmark$ \\
\hline Atezolizumab & $\begin{array}{l}\text { IMpower } 110 \\
\text { [NCT02409342] }\end{array}$ & $\begin{array}{l}\text { May 18, } \\
2020\end{array}$ & $\begin{array}{l}\text { Regular } \\
\text { Approval }\end{array}$ & $\begin{array}{l}\text { March 25, } \\
2021\end{array}$ & First-line & $\checkmark$ \\
\hline
\end{tabular}




\begin{tabular}{|lllllll|}
$\begin{array}{l}\text { Nivolumab + } \\
\text { pilimumab } \\
\text { combination (2 cycles } \\
\text { of platinum doublet) }\end{array}$ & $\begin{array}{l}\text { CheckMate 9LA } \\
\text { [NCT03215706] }\end{array}$ & $\begin{array}{l}\text { May 26, } \\
2020\end{array}$ & $\begin{array}{l}\text { Regular } \\
\text { Approval }\end{array}$ & $\begin{array}{l}\text { Application } \\
\text { Withdrawn }\end{array}$ & First-line & $\checkmark$ \\
\hline Cemiplimab & $\begin{array}{l}\text { EMPOWER- } \\
\text { Lung1 } \\
\text { [NCT03088540] }\end{array}$ & $\begin{array}{l}\text { February } \\
22,2021\end{array}$ & $\begin{array}{l}\text { Regular } \\
\text { Approval }\end{array}$ & $\begin{array}{l}\text { May 24, } \\
2021\end{array}$ & First-line & $\checkmark$ \\
\hline Atezolizumab & \begin{tabular}{llllll|} 
IMpower 010 \\
[NCT02486718]
\end{tabular} & $\begin{array}{lllll}\text { October } \\
15,2021\end{array}$ & $\begin{array}{l}\text { Regular } \\
\text { Approval }\end{array}$ & $\begin{array}{l}\text { No } \\
\text { Information }\end{array}$ & Third-line & - \\
\hline
\end{tabular}

Abbreviations: NSCLC: Non-Small Cell Lung Cancer, US: United States, FDA: Food and Drug Administration, EMA:
European Medicines Agency, PRO: Patient Reported Outcomes, NCT: National Clinical Trial

Figure 1 and Figure 2 show details of the decisions on approval, refusal or withdrawal of immune-checkpoint inhibitor indications by the FDA and the EMA, respectively. Both Figure 1 and Figure $\mathbf{2}$ further depict approval decision times (month year) for each regulatory agency.

Figure 3 shows the result of discordant-concordant approval outcomes when two regulatory agencies are compared. Discordant outcomes were defined as approvals for which the FDA and the EMA had different regulatory conclusions, namely; one agency approved the immune-checkpoint inhibitor while the other did not approve it, or one agency approved the immune-checkpoint inhibitor whereas the application was withdrawn (by the manufacturer) from the other agency. Concordant outcomes were defined as approvals for which both the FDA and the EMA had the same regulatory conclusion, namely; both agencies approved the drug indication; both agencies did not approve the drug indication; the drug application was withdrawn (by the manufacturer) from both agencies prior to a decision; or the drug application was not approved by one agency and withdrawn at the other agency.

Figure 4 shows differences of additional days between the EMA and the FDA to reach the same approval decision. For 15 of the identified 17 indications, the FDA was quicker to reach an approval decision, when compared with the EMA.

\section{Regulatory requirements for patient-reported outcomes}

From our analysis, PROs were included in the clinical trials and considered in 15 indications by the FDA and the EMA. Both the FDA and the EMA recognize the value of PROs as important patient-centered endpoints when determining the efficacy of therapies, and considering them for approval. The EMA began drafting recommendations regarding the use of PROs in 2004; and these recommendations were adopted in 2005 and 2016. [4] The FDA followed these efforts with a draft guidance published in 2006 and then updated in 2009. [5] Although these efforts highlight the importance of PROs in considerations of drug approvals, these two agencies are divergent in their approach. The documents from the EMA indicated that the agency's primary concern was to acknowledge the importance of improvement in patient-reported health-related quality of life (HRQOL). [6] The PRO guidance from the EMA centers on multiple domains for generalized assessment of HRQOL, while the FDA focuses on symptom-specific measures. In addition, the EMA incorporates the HRQOL data from clinical trials in their assessment, however there is no mention of this endpoint in the FDA assessments. The FDA is explicit in its requirements for the development and use of PROs as an outcome in a clinical trial. [7] This trend toward more specific requirements indicates that the FDA favors symptom-specific 
assessments over global HRQOL assessments. Moreover, the FDA usually considers PROs as a supplemental or exploratory endpoint for the demonstration of clinical efficacy rather than as part of the primary evaluation criteria.

Although both agencies note the role and value of these PRO measures in bringing the patient's perspective to the drug assessment, the approach by the FDA regarding PRO development and validation is more stringent than that of the EMA. Further harmonization and collaboration between the EMA and the FDA on the PRO instrument development, measurement and validation are encouraged to increase the efficiency of the decisionmaking processes in the future.

\section{Discussion}

There is concern that regulation hampers drug development and slows drug approvals, because of costs incurred by the drug manufacturers in their efforts to meet requirements that may be excessive and duplicative. In this study, we analyzed the differences in regulatory approvals between the FDA and the EMA for immunecheckpoint inhibitors in the treatment of NSCLC from year 2015 until 2021 based on: (1) time to approval of immune-checkpoint inhibitors, and (2) the considerations of patient-reported outcomes (PROs) by each agency. Our analysis showed that the indications that stood out in terms of outcome divergence were mainly first-line options for treatment naïve patients. The preponderance of outcome differences in approvals was not influenced by the expedited development and access programs, marked by the FDA Safety and Innovation Act, established the FDA's Breakthrough Therapy designation in 2012, [8] or the EMA's Priority Medicines (PRIME) scheme, established in 2016. [9] In our analysis, there were two clinical trial (NCT01905657, NCT02039674) applications that underwent accelerated approval process by the FDA. Accelerated approval pathways advanced by both the FDA and the EMA are among the reform efforts frequently taken advantage of by the manufacturers for their drug development programs. Section 901 of the Safety Innovations Act (FDASIA) of 2012 permits use of surrogate endpoints which then allows demonstration of efficacy within a shorter period of time. [10] Despite similarities in the regulatory pathways and assessments used for immune-checkpoint inhibitor approvals, there are differences between the two agencies in time to approval or marketing authorization for these drugs. Our study showed that the FDA approves immune-checkpoint inhibitors for NSCLC more quickly than the EMA. This finding demonstrates a key difference between the authority of the two agencies. We would like to emphasize that while the FDA both scientifically evaluates new agents and issues marketing authorization decisions for drug or products, the scope of the EMA's Committee for Medicinal Products for Human Use (CHMP) is limited only to the scientific evaluation. Based on the CHMP assessment, the EMA makes recommendations to the European Commission (EC) for marketing approval of the drug. Decoupling of the scientific approval process and the marketing approval process may lead to additional postponements for patient access. Moreover, the differences between the US and Europe in the use of immune-checkpoint inhibitors arise because each EU member state has its own system for determining which drugs will have the marketing authorization by that member state. Outside of the member states, in the United Kingdom (UK), a new drug can apply for a license through the Medicines and Healthcare products Regulatory Agency (MHRA), or go through the EMA. If the agent is approved by the EMA, then it must be approved by the MHRA in order to be marketed in the UK. In addition, the National Institute for Health and Care Excellence must then evaluate the drug for costeffectiveness and affordability criteria in order to determine whether the agent that has been approved by the MHRA will actually be purchased by the National Health Service. [11,12]

Page 6/12 
With regards to the PROs, the $21^{\text {st }}$ Century Cures Act [13] outlines ways to incorporate patients' experience into drug development and regulatory review processes. [14] There is evidence that monitoring treatment side effects in real time can improve outcomes for patients with cancer, including a potential benefit in survival rates. [15] Previous research had shown that PRO data captured during treatment may increase accuracy in the assessment of patients' experience of symptomatic side effects compared with physician reports, because physicians may underreport the frequency or severity of side effects. [16] NSCLC is classified as a high tumor mutational burden cancer. [17] During or after immunotherapy, patients may experience immune-related adverse events (irAEs), in addition to commonly reported treatment-related side effects. [17] Although patients' assessments of the incidence and consequences of these irAEs are important, existing cancer-specific PRO instruments $[18,19]$ were not designed to capture irAEs, and may not fully reflect the benefits and toxicity profiles of immunotherapies. Clinical trial guidelines that promote transparent and accurate reporting of PROs, in an effort to facilitate interpretation of these complex data and their limitations, are further compounded by factors such as the unblinded nature of the NSCLC clinical trials. [20,21] Furthermore, PROs are increasingly included in health technology assessments, and have important ramifications on patient access, drug reimbursement and pricing. The importance of collecting appropriate PROs is also reflected in the updated the FDA and the EMA drug approval guidelines. $[4,5]$

All in all, efforts to align regulatory practices, with high concordance approval outcomes, can lead to decreased costs associated with drug development. These efforts can also provide a more streamlined and predictable process for evaluation of the efficacy, safety and PRO measures for new drugs or disease indications. While significant steps have been taken to harmonize and align drug regulatory practices, there remain differences in outcomes that have consequences for patients' timely access to NSCLC therapies. Adhering to mutually agreed upon processes has the potential to lower barriers to drug development, and eliminate redundant processes that affect both the availability of safe and effective drugs to patients, and the sustainability of the healthcare systems in Europe, the United States and beyond.

\section{Declarations}

\section{Funding source}

This research did not receive any specific grant from funding agencies in the public, commercial, or not-for-profit sectors.

\section{Author Contributions}

Remziye Zaim: Conceptualization, Data curation, Writing- original draft manuscript, Figures and Table preparation.

Ken Redekop and Carin A. Uyl-de Groot: Supervision.

Remziye Zaim, Ken Redekop and Carin A. Uyl-de Groot: Writing- reviewing and editing the manuscript.

\section{Conflicts of Interest}

None. 


\section{References}

1. The International Council for Harmonization of Technical Requirements for Pharmaceuticals for Human Use. https://www.ich.org (accessed 6 Feb 2022).

2. European Medicines Agency. Cluster activities. https://www.ema.europa.eu/en/partnersnetworks/international-activities/cluster-activities

3. Topalian SL, Drake CG, Pardoll DM. Immune checkpoint blockade: a common denominator approach to cancer therapy. Cancer Cell 2015;27:450-61. doi:10.1016/j.ccell.2015.03.001

4. European Medicines Agency. Appendix 2 to the guideline on the evaluation of anticancer medicinal products in man The use of patient-reported outcome (PRO) measures in oncology studies.

EMA/CHMP/292464/2014. 2016. https://www.ema.europa.eu/en/documents/other/appendix-2-guidelineevaluation-anticancer-medicinal-products-man_en.pdf (accessed 2 Jan 2022).

5. The US Food and Drug Administration Guidance for Industry Patient-Reported Outcome Measures: Use in Medical Product Development to Support Labeling Claims. 2009. https://www.fda.gov/media/77832/download (accessed 2 Jan 2022).

6. European Medicines Agency. Reflection Paper on the Regulatory Guidance for the use of Health-Related Quality of Life (HRQoL) Measures in the Evaluation of Medicinal Products. https://www.ema.europa.eu/en/documents/scientific-guideline/reflection-paper-regulatory-guidance-usehealthrelated-quality-life-hrql-measures-evaluation_en.pdf (accessed 6 Feb 2022).

7. Bottomley A, Jones D, Claassens L. Patient-reported outcomes: assessment and current perspectives of the guidelines of the Food and Drug Administration and the reflection paper of the European Medicines Agency. Eur J Cancer 2009;45:347-53. doi:10.1016/j.ejca.2008.09.032

8. The US Food and Drug Administration. Guidance for Industry Expedited Programs for Serious Conditions Drugs and Biologics. https://www.fda.gov/media/86377/download (accessed 6 Feb 2022).

9. European Medicines Agency. Enhanced early dialogue to facilitate accelerated assessment of PRlority Medicines (PRIME). https://www.ema.europa.eu/en/documents/regulatory-procedural-guideline/enhancedearly-dialogue-facilitate-accelerated-assessment-priority-medicines-prime_en.pdf (accessed 6 Feb 2022).

10. The US Food and Drug Administration. Food and Drug Administration Safety and Innovation Act (FDASIA). https://www.fda.gov/regulatory-information/selected-amendments-fdc-act/food-and-drug-administrationsafety-and-innovation-act-fdasia

11. National Institute for Health and Care Excellence. Guidance. https://www.nice.org.uk/about (accessed 22 Jan 2022).

12. The United Kingdom Medicines \& Healthcare Products Regulatory Agency. https://www.gov.uk/government/organisations/medicines-and-healthcare-products-regulatory-agency

13. 21st Century Cures Act. H.R.34-114th Congress (2015-2016). https://www.congress.gov/bill/114thcongress/house-bill/34/ (accessed 2 Jan 2022).

14. CDER Patient-Focused Drug Development. https://www.fda.gov/drugs/development-approval-processdrugs/cder-patient-focused-drug-development (accessed 4 Jan 2022).

15. Basch E, Deal AM, Dueck AC, et al. Overall Survival Results of a Trial Assessing Patient-Reported Outcomes for Symptom Monitoring During Routine Cancer Treatment. JAMA 2017;318:197. 
doi:10.1001/jama.2017.7156

16. Di Maio M, Gallo C, Leighl NB, et al. Symptomatic toxicities experienced during anticancer treatment: agreement between patient and physician reporting in three randomized trials. J Clin Oncol 2015;33:910-5. doi:10.1200/JC0.2014.57.9334

17. Wang D, Chen C, Gu Y, et al. Immune-Related Adverse Events Predict the Efficacy of Immune Checkpoint Inhibitors in Lung Cancer Patients: A Meta-Analysis. Front Oncol 2021;11:631949. doi:10.3389/fonc.2021.631949

18. Aaronson NK, Ahmedzai S, Bergman B, et al. The European Organization for Research and Treatment of Cancer QLQ-C30: a quality-of-life instrument for use in international clinical trials in oncology. J Natl Cancer Inst 1993;85:365-76. doi:10.1093/jnci/85.5.365

19. Hollen PJ, Gralla RJ, Kris MG, et al. Measurement of quality of life in patients with lung cancer in multicenter trials of new therapies. Psychometric assessment of the Lung Cancer Symptom Scale. Cancer 1994;73:2087-98. doi:10.1002/1097-0142(19940415)73:8<2087::aid-cncr2820730813>3.0.c0;2-x

20. Calvert M, Blazeby J, Altman DG, et al. Reporting of patient-reported outcomes in randomized trials: the CONSORT PRO extension. JAMA 2013;309:814-22. doi:10.1001/jama.2013.879

21. Brundage M, Blazeby J, Revicki D, et al. Patient-reported outcomes in randomized clinical trials: development of ISOQOL reporting standards. Qual Life Res 2013;22:1161-75. doi:10.1007/s11136-0120252-1

\section{Figures}



Abbreviations: 1L: First line, 2L: Second line, 3L: Third line, NSCLC: Non-small cell lung cancer, N:

Nivolumab, P: Pembrolizumab, A: Atezolizumab, D: Durvalumab, C: Cemiplimab

\section{Figure 1}

Immune-checkpoint inhibitor approvals by the US Food and Drug Administration for non-small cell lung cancer 


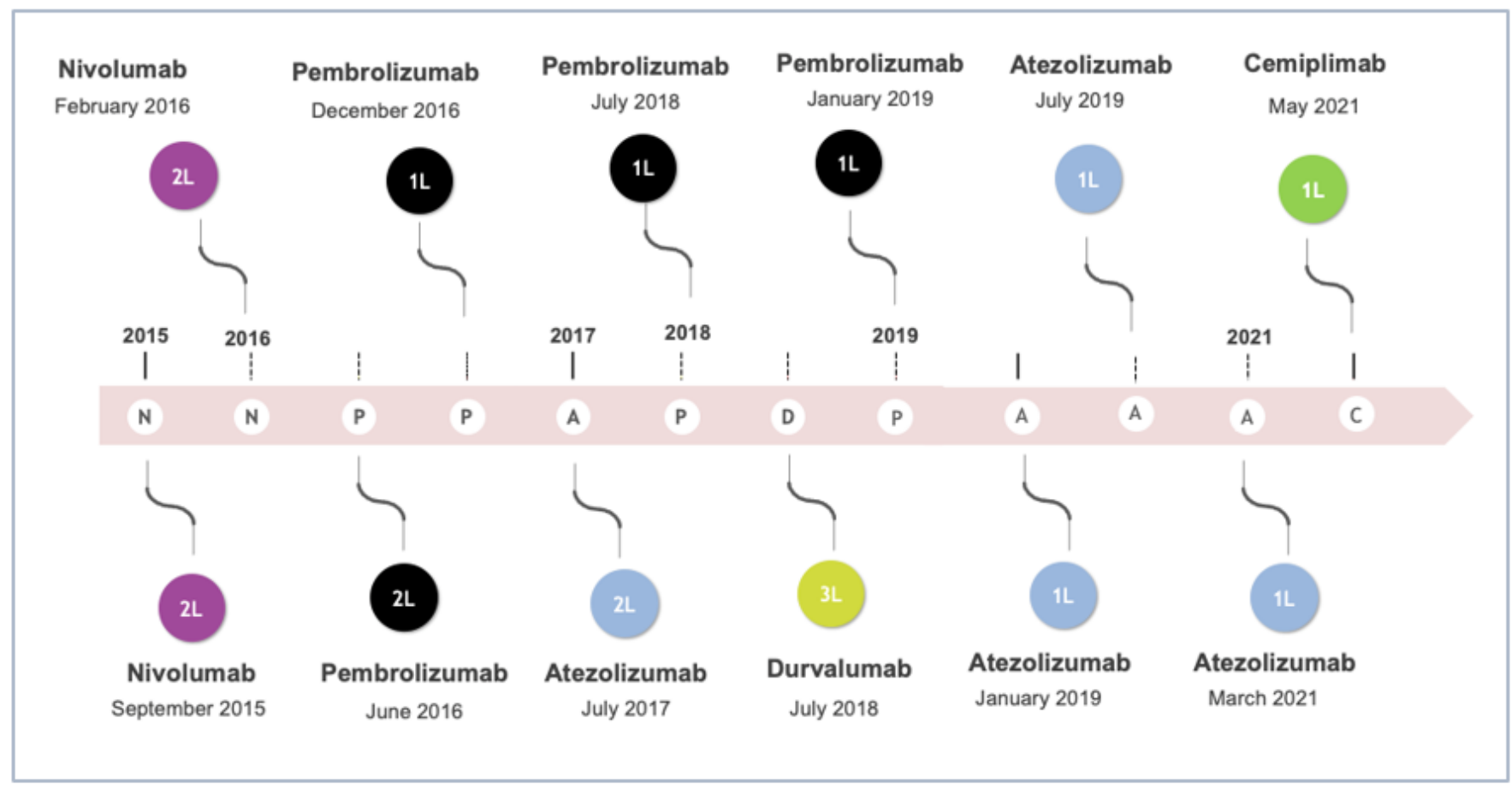

Abbreviations: 1L: First line, 2L: Second line, 3L: Third line, NSCLC: Non-small cell lung cancer, N: Nivolumab, P: Pembrolizumab, A: Atezolizumab, D: Durvalumab, C: Cemiplimab

\section{Figure 2}

Immune-checkpoint inhibitor approvals by the European Medicines Agency for non-small cell lung cancer 


\section{Discordance-Concordance of Regulatory Approvals of NSCLC Immune- Checkpoint Inhibitors in the United States versus Europe [2015-2021]}

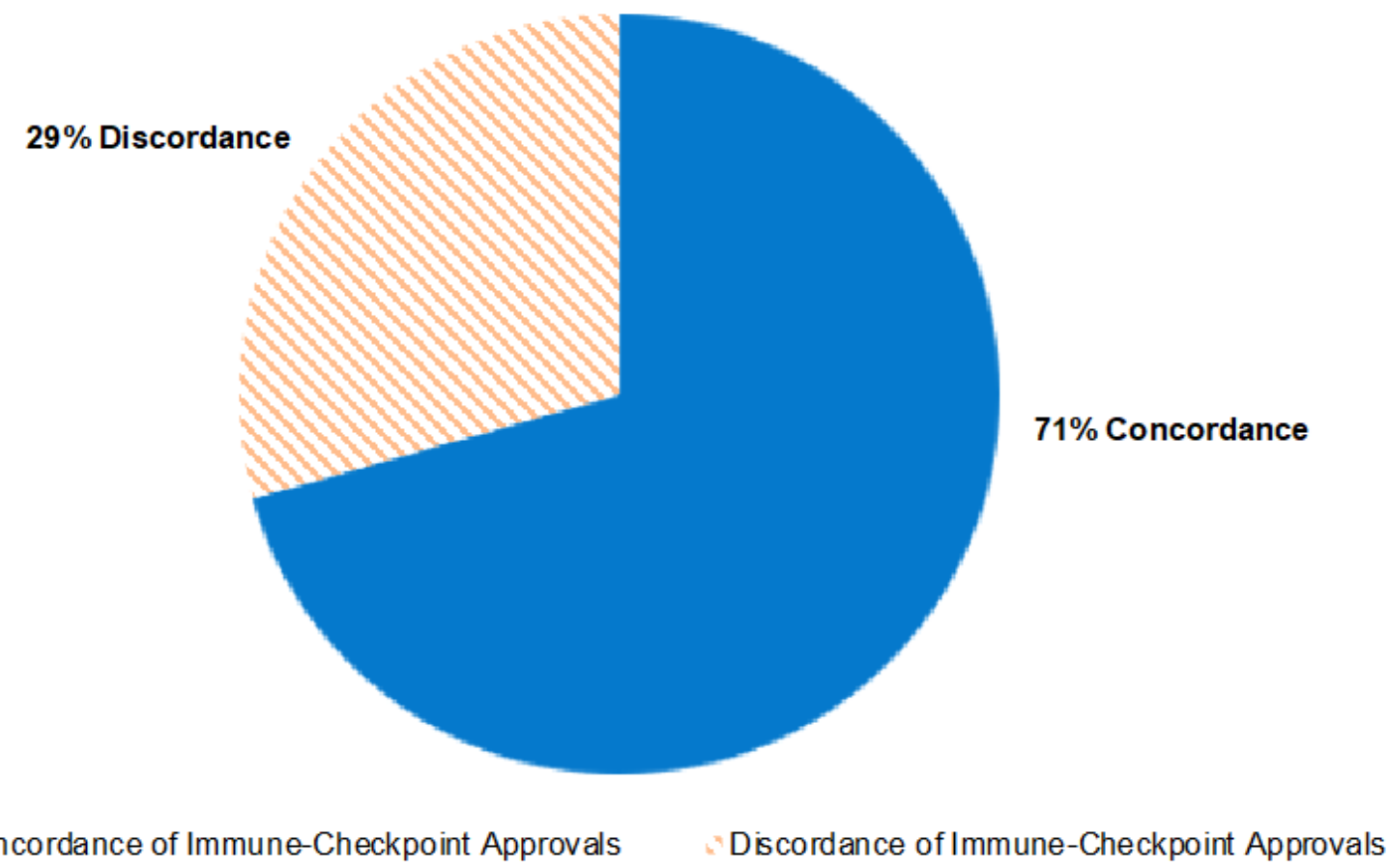

\section{Figure 3}

Discordance-Concordance of immune-checkpoint inhibitor approvals by the US Food and Drug Administration compared to the European Medicines Agency for non-small cell lung cancer [2015-2021] 


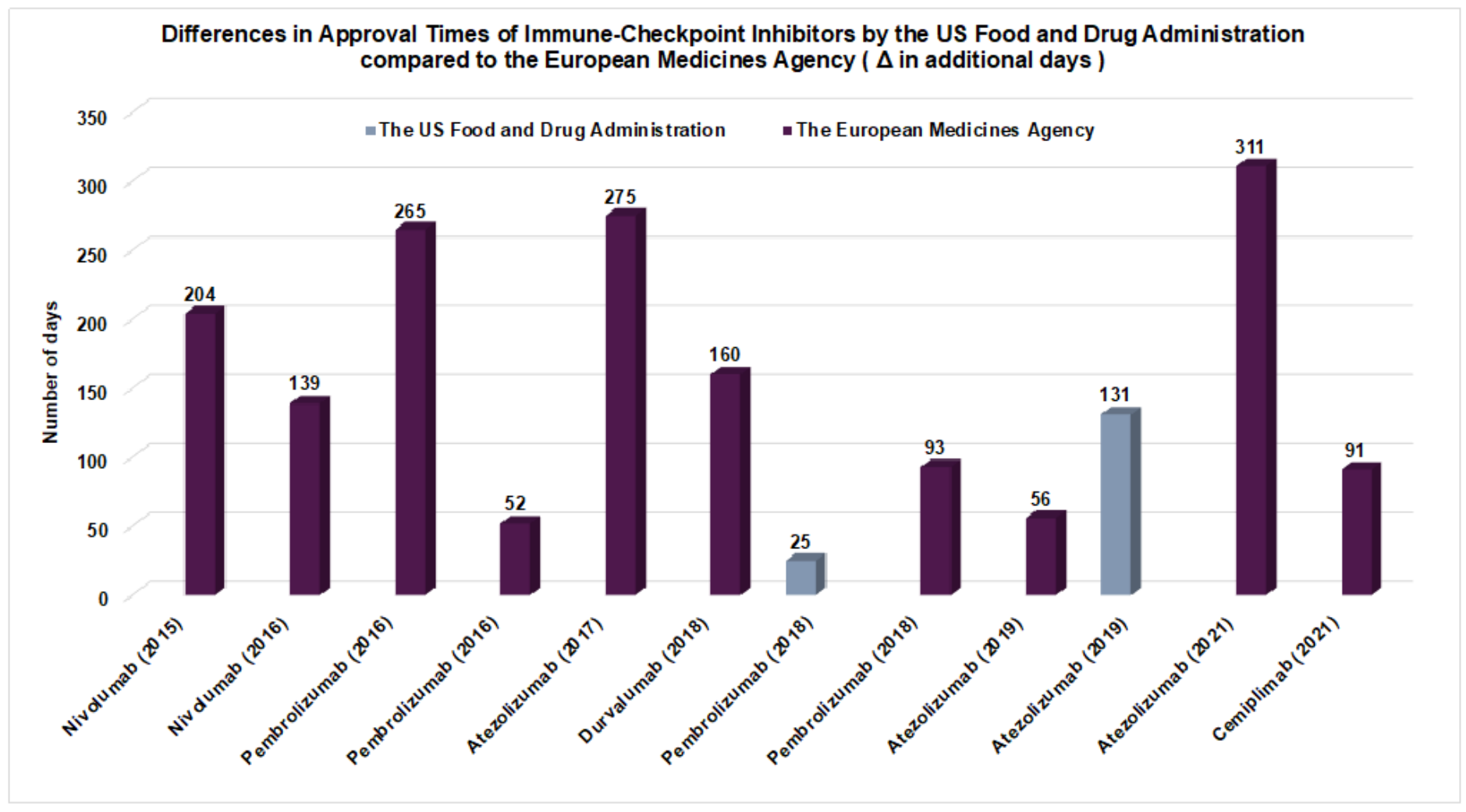

$\Delta$ : change or difference

\section{Figure 4}

Differences of Approvals of Immune-Checkpoint Inhibitors by the US Food and Drug Administration and the European Medicines Agency ( $\Delta$ in additional days) 